\title{
Synthesis, Characterization, and $X$-Ray Structure of Bis(O-butyldithiocarbonato)bis(3-ethyl pyridine)nickel(II)
}

\author{
Inderjeet Kaur, ${ }^{1}$ Kuldeep Singh, ${ }^{2}$ Gurvinder Kaur, ${ }^{2}$ Renu Sachar, ${ }^{1}$ \\ Vivek K. Gupta, ${ }^{2}$ and Rajni Kant ${ }^{2}$ \\ ${ }^{1}$ Department of Chemistry, University of Jammu, Jammu Tawi 180 006, India \\ ${ }^{2}$ X-Ray Crystallography Laboratory, Post Graduate Department of Physics and Electronics, University of Jammu, \\ Jammu Tawi 180 006, India
}

Correspondence should be addressed to Rajni Kant; rkvk.paper1l@gmail.com

Received 21 January 2014; Accepted 6 March 2014; Published 30 April 2014

Academic Editor: Takashi Mino

Copyright (C) 2014 Inderjeet Kaur et al. This is an open access article distributed under the Creative Commons Attribution License, which permits unrestricted use, distribution, and reproduction in any medium, provided the original work is properly cited.

\begin{abstract}
A new series of additional complexes of bis(O-butyldithiocarbonato)nickel(II) with ethylpyridines have been prepared and characterized by physicochemical techniques like elemental analysis, molar conductance measurements, TGA-DTA and UVvisible electronic spectroscopy, and IR-spectral data. The structure of $\left[\mathrm{Ni}\left(\mathrm{S}_{2} \mathrm{COC}_{4} \mathrm{H}_{9}\right)_{2}\left(\mathrm{C}_{7} \mathrm{H}_{9} \mathrm{~N}\right)_{2}\right]$ has been established by X-ray crystallography. The complex crystallizes in the monoclinic space group P1/n with unit cell parameters $a=14.0721(6), b=7.0078(2)$, and $c=15.3604(7) \AA$ and $\alpha=90.00, \beta=108.065(5)$, and $\gamma=90.00^{\circ}$. The Ni atom in the title complex is octahedrally coordinated within a trans- $\mathrm{N}_{2} \mathrm{~S}_{4}$ donor set, with the $\mathrm{Ni}$ atom located on a centre of inversion. Crystal structure was solved by direct methods and refined by full matrix least squares procedures to a final $R$-value of 0.0545 for 1984 observed reflections. The butyl chain is disordered over two sets of sites, with occupancy ratio of $0.572: 0.427$.
\end{abstract}

\section{Introduction}

O-alkyldithiocarbonate $\left(\mathrm{ROCS}_{2}{ }^{-}\right)$, named xanthate, represents an important class of 1,1 dithiolato ligands which have been studied extensively $[1,2]$. These compounds form water insoluble complexes with most of the transition metals and are thus extensively employed for the separation and quantitative determination of cations of transition metals [3]. Beside this these ligands are also investigated for nonlinear optical application and as a synthetic precursor for the generation of metal sulfide nanoparticles $[4,5]$. Xanthates as ligand are also extensively studied for a wide variety of structural features. They are known to coordinate as a monodentate, bidentate, or as a bridging ligand. Xanthate complexes of composition $\left[\mathrm{Ni}(\mathrm{Rxa})_{2}\right](\mathrm{R}=$ alkyl; $\mathrm{xa}=$ xanthate) are partially unsaturated and thus they can react easily with monodentate or bidentate nitrogen donor ligands and afford octahedral nickel(II) complexes with either cis or trans geometry. As a part of our ongoing research on nickel(II) xanthate complexes with substituted pyridines, we report here the synthesis and characterization of $1: 2$ adducts of bis(O-butyldithiocarbonato)nickel(II) with ethyl pyridines and also the crystal structure of the adduct bis $(O$ butyldithiocarbonato)bis(3-ethylpyridine)nickel(II).

\section{Experimental}

2.1. Material and Measurement. Carbon, hydrogen, sulphur, and nitrogen contents of the addition complexes are determined on elemental analyzer CHNS 932, LECO Corporation, USA. Molar conductance of adducts was determined on their millimolar4 solutions in DMF by using digital conductivity meter "Century CC 601." Infrared spectra of the complexes over the region $4000-200 \mathrm{~cm}^{-1}$ were recorded using $\mathrm{KBr}$ pellets on the infrared spectrometer (PerkinElmer FT-IR spectrometer). The electronic spectra of adducts were recorded in DMF on systronics 119 UV-visible spectrophotometer. Magnetic moments were recorded at room temperature by VSM method (Princeton applied research model number 155). The analytical data, molar conductance, and magnetic 
TABLE 1: Physical and analytical data of the adducts of bis(O-butyldithiocarbonato)nickel(II) with substituted pyridines.

\begin{tabular}{|c|c|c|c|c|c|c|c|}
\hline \multirow{2}{*}{ Complex } & \multirow{2}{*}{ Formula Wt. } & \multirow{2}{*}{ M.P $\left({ }^{\circ} \mathrm{C}\right)$} & \multirow{2}{*}{$\mu_{\mathrm{eff}}(\mathrm{B} . \mathrm{M})$} & \multicolumn{4}{|c|}{ Found (calculated) \% } \\
\hline & & & & $\mathrm{C}$ & $\mathrm{H}$ & $\mathrm{N}$ & $S$ \\
\hline $\begin{array}{l}\text { Bis(O-butyldithiocarbonato) } \\
\text { bis(2-ethylpyridine)nickel(II) }\end{array}$ & 572.69 & 79.8 & 3.10 & $\begin{array}{c}50.28 \\
(48.95) \\
\end{array}$ & $\begin{array}{c}6.28 \\
(5.88) \\
\end{array}$ & $\begin{array}{c}4.88 \\
(4.35) \\
\end{array}$ & $\begin{array}{c}22.35 \\
(22.05) \\
\end{array}$ \\
\hline $\begin{array}{l}\text { Bis(O-butyldithiocarbonato) } \\
\text { bis(3-ethylpyridine)nickel(II) }\end{array}$ & 572.69 & 80 & 3.27 & $\begin{array}{c}50.28 \\
(49.01) \\
\end{array}$ & $\begin{array}{c}6.28 \\
(5.93) \\
\end{array}$ & $\begin{array}{c}4.88 \\
(4.05)\end{array}$ & $\begin{array}{l}22.35 \\
(22.0) \\
\end{array}$ \\
\hline $\begin{array}{l}\text { Bis(O-butyldithiocarbonato) } \\
\text { bis(4-ethylpyridine)nickel(II) }\end{array}$ & 572.69 & 80.2 & 3.28 & $\begin{array}{c}50.28 \\
(48.82)\end{array}$ & $\begin{array}{c}6.28 \\
(6.01)\end{array}$ & $\begin{array}{c}4.88 \\
(4.43)\end{array}$ & $\begin{array}{c}22.35 \\
(21.95)\end{array}$ \\
\hline
\end{tabular}

TABLE 2: Infrared and electronic spectral data of the adducts of bis(O-butyldithiocarbonato)nickel(II) with substituted pyridines.

\begin{tabular}{lccccc}
\hline Complex & \multicolumn{2}{c}{ IR-spectral data $\left(\mathrm{cm}^{-1}\right)$} & \multicolumn{3}{c}{ Electronic spectral data $\left(\mathrm{cm}^{-1}\right)$} \\
$v_{2}$ & $v_{1}$ & 19800 \\
\hline $\begin{array}{l}\text { Bis(O-butyldithiocarbonato) } \\
\text { bis(2-ethylpyridine)nickel(II) }\end{array}$ & 1202 & 1123 & 1033 & 14440 & 26400 \\
\hline $\begin{array}{l}\text { Bis(O-butyldithiocarbonato) } \\
\text { bis(3-ethylpyridine)nickel(II) }\end{array}$ & 1199 & 1134 & 1035 & 13980 & 20220 \\
\hline $\begin{array}{l}\text { Bis(O-butyldithiocarbonato) } \\
\text { bis(4-ethylpyridine)nickel(II) }\end{array}$ & 1199 & 1140 & 1037 & 14250 & 19225 \\
\hline
\end{tabular}

moments of adducts are represented in Table 1. Important IR bands and electronic spectral data are cited in Table 2.

The X-ray intensity data for the compound, bis(O-butyldithiocarbonato)bis(3-ethylpyridine)nickel(II) (Figure 1), were collected by using X'calibur Oxford diffraction system with graphite monochromatic $\operatorname{MoK} \alpha$ radiation $(\lambda=0.71073 \AA)$. Data were collected by using CrysAlis ${ }^{\text {Pro }}$ software and reduced with CrysAlisRED [6]. The final refinement cycles converged to an $R=0.0545$ and $w R\left(F^{2}\right)=0.1293$ for observed data. The residual electron densities had the range of $-0.419<\Delta \rho<0.790 \mathrm{e}^{-3}$. The structure was solved by SHELXS97 [7] and refined with SHELXL97 [7]. The H atoms were positioned geometrically and were treated as riding on their parent $\mathrm{C}$ atoms, with $\mathrm{C}-\mathrm{H}$ distance of $0.93-0.97 \AA$ and with $U_{\text {iso }}=1.2 U_{\text {eq }}(\mathrm{C})$ or $1.5 U_{\text {eq }}$ (methyl C).

\subsection{Synthesis of the Title Complex}

2.2.1. Preparation of Potassium Butyldithiocarbonate. The potassium salt of O-butyldithiocarbonate was prepared by the standard published method [8]. Into a $500 \mathrm{~mL}$ round bottomed flask, fitted with a reflux condenser, $42 \mathrm{~g}(0.075 \mathrm{~mol})$ of potassium hydroxide pellets was placed and $192 \mathrm{~g}(234 \mathrm{~mL}$, $2.6 \mathrm{~mol}$ ) of $\mathrm{n}$-butanol was added. The reaction mixture was heated under reflux for 1 hour. The contents were then cooled and the liquid from the reaction mixture was decanted off into another dry $500 \mathrm{~mL}$ flask. To this flask, $57 \mathrm{~g}(45 \mathrm{~mL}$, $0.075 \mathrm{~mol}$ ) of carbon disulphide was added slowly with constant heating. The contents of the flask were filtered (after cooling in ice) on a sintered glass funnel at the pump and washed with three $25 \mathrm{~mL}$ portions of ether. The resulting product potassium $\mathrm{O}$-butyldithiocarbonate was dried in a vacuum desiccator over anhydrous calcium chloride.
2.2.2. Synthesis of Bis(O-butyldithiocarbonato)nickel(II). The complex bis(O-butyldithiocarbonato)nickel(II) was prepared by stirring aqueous solutions of nickel(II) chloride and potassium salt of O-butyldithiocarbonate in the molar ratio of 1:2 when green colored precipitates of bis $(\mathrm{O}$ butyldithiocarbonato)nickel(II) were obtained.

\subsubsection{Synthesis of Bis(O-butyldithiocarbonato)bis(ethylpyri-} dine)nickel(II). To a solution of $\left[\mathrm{Ni}\left(\mathrm{S}_{2} \mathrm{COC}_{4} \mathrm{H}_{9}\right)_{2}\right](0.79 \mathrm{~g}$, 0.0026 mole $)$ in acetone $(50 \mathrm{~mL})$ corresponding ethylpyridine (2-ethylpyridine, 3-ethylpyridine, and 4-ethylpyridine) (each $0.56 \mathrm{~g}, 0.0052 \mathrm{~mol}$ ) was added with constant stirring for 30 minutes. The color of the solution changes to bright green. The resulting solution was allowed to stand for few days at room temperature when bright green crystals of $\left[\mathrm{Ni}\left(\mathrm{S}_{2} \mathrm{COC}_{4} \mathrm{H}_{9}\right)_{2}\left(\mathrm{C}_{7} \mathrm{H}_{9} \mathrm{~N}\right)_{2}\right]$ were obtained.

\section{Results and Discussion}

3.1. Preliminary Investigations. The adducts of bis(O-butylxanthato)nickel(II) with 2-, 3-, and 4-ethylpyridine are bright green colored microcrystalline solids which are soluble in acetone, chloroform, DMF, and DMSO. On the basis of elemental analysis the adducts isolated having $1: 2$ stoichiometry are assigned formula $\left[\mathrm{Ni}\left(\mathrm{S}_{2} \mathrm{COC}_{4} \mathrm{H}_{9}\right)_{2}\right] \mathrm{L}_{2}$ where $\mathrm{L}=2-, 3-$, and 4-ethylpyridine.

3.2. Conductance and Magnetic Measurements. The molar conductivity value calculated from the conductivity measurements of millimolar solution of the title complex in DMF supports the neutral and nonionic nature of the complex $[9,10]$. The effective room temperature magnetic moment of the complex prepared was found to be 3.28 B.M. which 


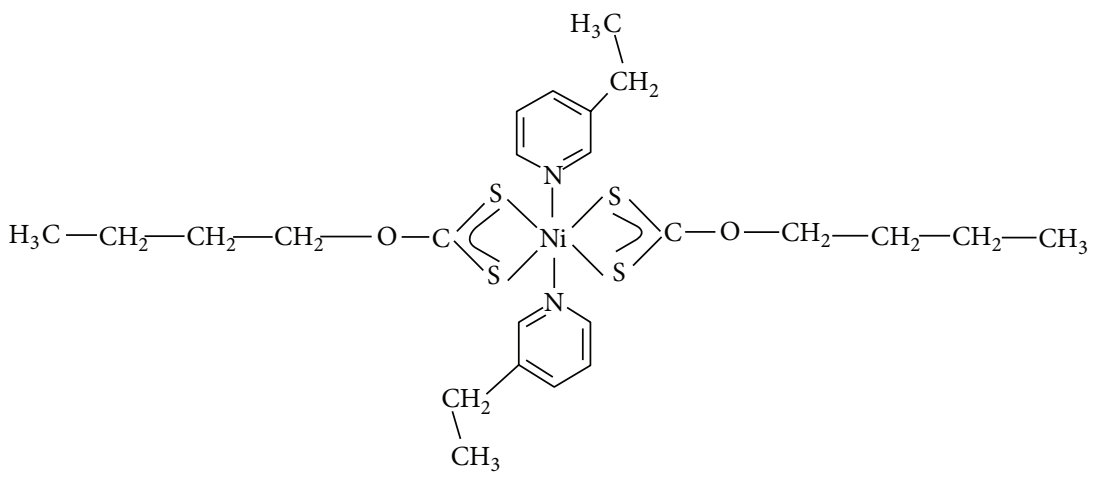

FIgURE 1: Chemical structure of bis(O-butyldithiocarbonato)bis(3-ethyl pyridine)nickel(II).

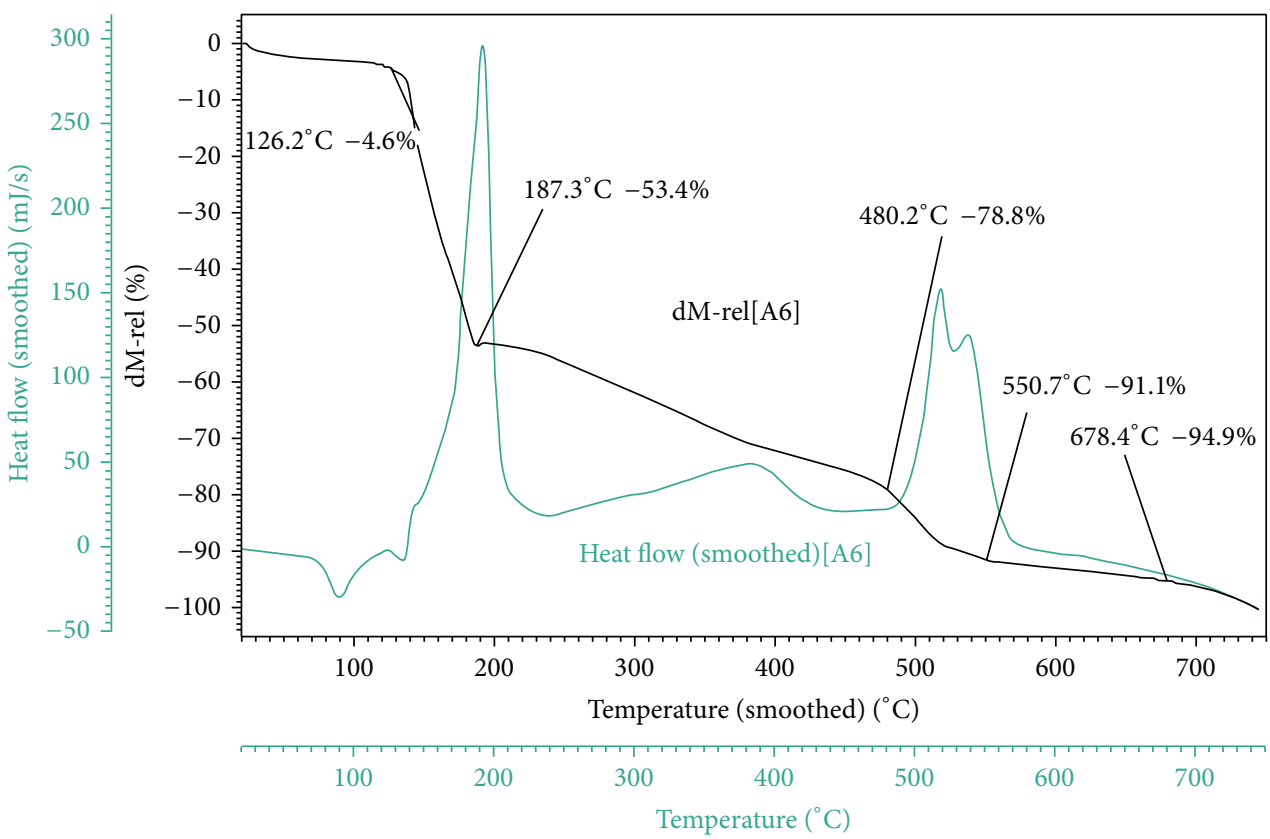

FIGURE 2: TGA curve of the bis(O-butyldithiocarbonato)bis(3-ethylpyridine)nickel(II).

is in agreement with magnetic moment values observed for paramagnetic octahedral complexes of nickel(II) [11].

3.3. IR and Electronic Spectra. The infrared spectrum of the complex $\left[\mathrm{Ni}\left(\mathrm{S}_{2} \mathrm{CoC}_{4} \mathrm{H}_{9}\right)_{2}\left(\mathrm{C}_{7} \mathrm{H}_{9} \mathrm{~N}\right)_{2}\right]$ exhibits characteristic bands for xanthato ligand [12] at 1201 and $1144 \mathrm{~cm}^{-1}$ which are attributed to the stretching vibration of the $\mathrm{C}-\mathrm{O}-\mathrm{C}$ group, while the bands at $1037 \mathrm{~cm}^{-1}$ and $614 \mathrm{~cm}^{-1}$ belong to $\nu(\mathrm{C}-\mathrm{S})$ vibration [13]. The bands at 1580 and 1540 for $\nu(\mathrm{C}=\mathrm{N})$, and at $1450 \mathrm{~cm}^{-1}$ for $\nu(\mathrm{C}=\mathrm{C})$, belong to coordinated 3-ethylpyridine ligand. The electronic absorption spectra show absorption bands $v_{1}\left(14800 \mathrm{~cm}^{-1}\right), v_{2}\left(19200 \mathrm{~cm}^{-1}\right)$, and $v_{3}\left(23500 \mathrm{~cm}^{-1}\right)$, which probably corresponds to the $\mathrm{d}$-d transitions ${ }^{3} \mathrm{~A}_{2} \mathrm{~g} \rightarrow$ ${ }^{3} \mathrm{~T}_{2} \mathrm{~g}(\mathrm{~F}),{ }^{3} \mathrm{~A}_{2} \mathrm{~g} \rightarrow{ }^{3} \mathrm{~T}_{1} \mathrm{~g}(\mathrm{~F})$, and ${ }^{3} \mathrm{~A}_{2} \mathrm{~g} \rightarrow{ }^{3} \mathrm{~T}_{1} \mathrm{~g}(\mathrm{P})$, respectively. Appearance of these three broad bands along with shoulders shows that adduct is having trans octahedral geometry around nickel(II) metal ion [14].
3.4. TGA/DTA Studies. The TGA/DTA studies of the complex prepared were carried out from 20 to $750^{\circ} \mathrm{C}$ at the rate of $10^{\circ} \mathrm{C} / \mathrm{min}$. The TGA curve of the title complex is shown in Figure 2. The complex first decomposes at $126.2^{\circ} \mathrm{C}$ showing the loss of an alkyl moiety (weight loss found = $4.7 \%$, calculated $=4.5 \%)$. The DTA curve shows a sharp endothermic peak below $100^{\circ} \mathrm{C}$ indicating that the water molecules are present outside the coordination sphere. A major loss occurs at $187.3^{\circ} \mathrm{C}$ which corresponds to the loss of xanthato group (weight loss $=53.3 \%$ calculated $=49.5 \%$ ). This loss has also been supported by sharp exothermic curve at the same temperature. With the rise in temperature, the weight loss was found to be $88.9 \%$ at $678.4^{\circ} \mathrm{C}$ indicating the loss of both the molecules of 3-ethylpyridine (weight loss found = $88.9 \%$, calculated $=88.3 \%$ ). It has also been supported by the DTA curve. The weight loss continues at a slower rate up to $750^{\circ} \mathrm{C}$ leaving behind stable $\mathrm{NiO}$. 


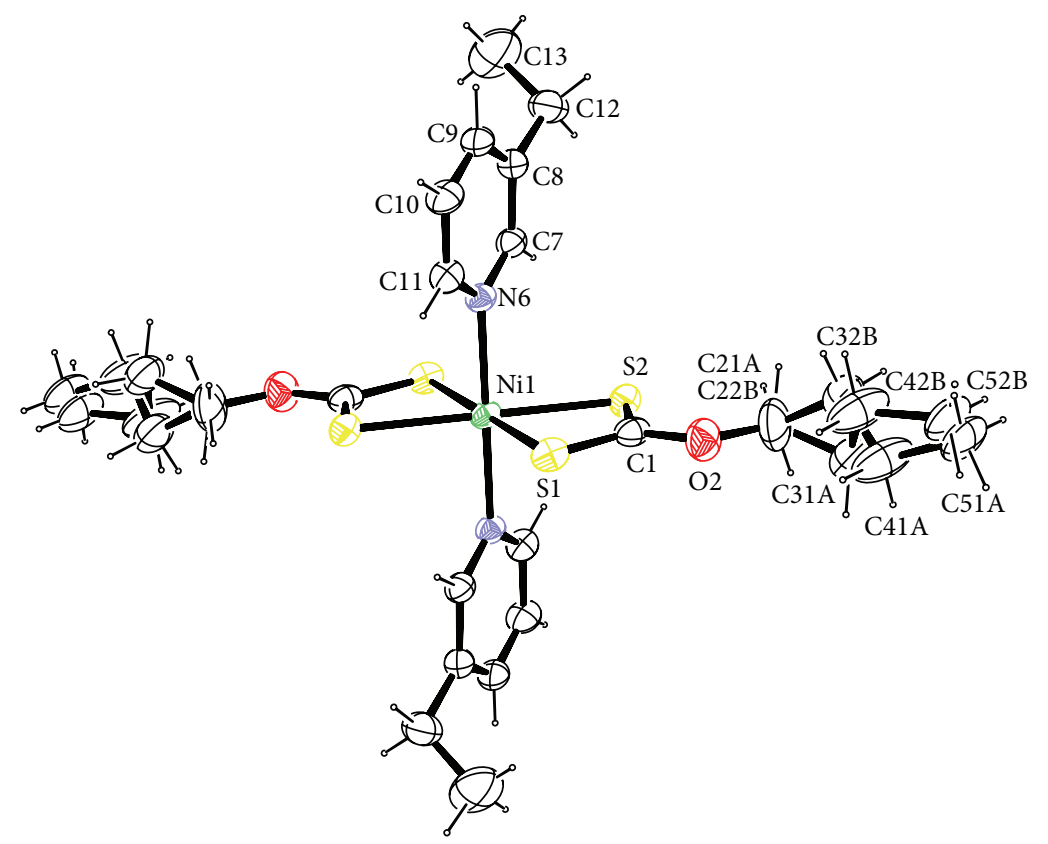

FIGURE 3: ORTEP view of the molecule with displacement ellipsoids drawn at the $50 \%$ probability level. $\mathrm{H}$ atoms are shown as small spheres of arbitrary radii.

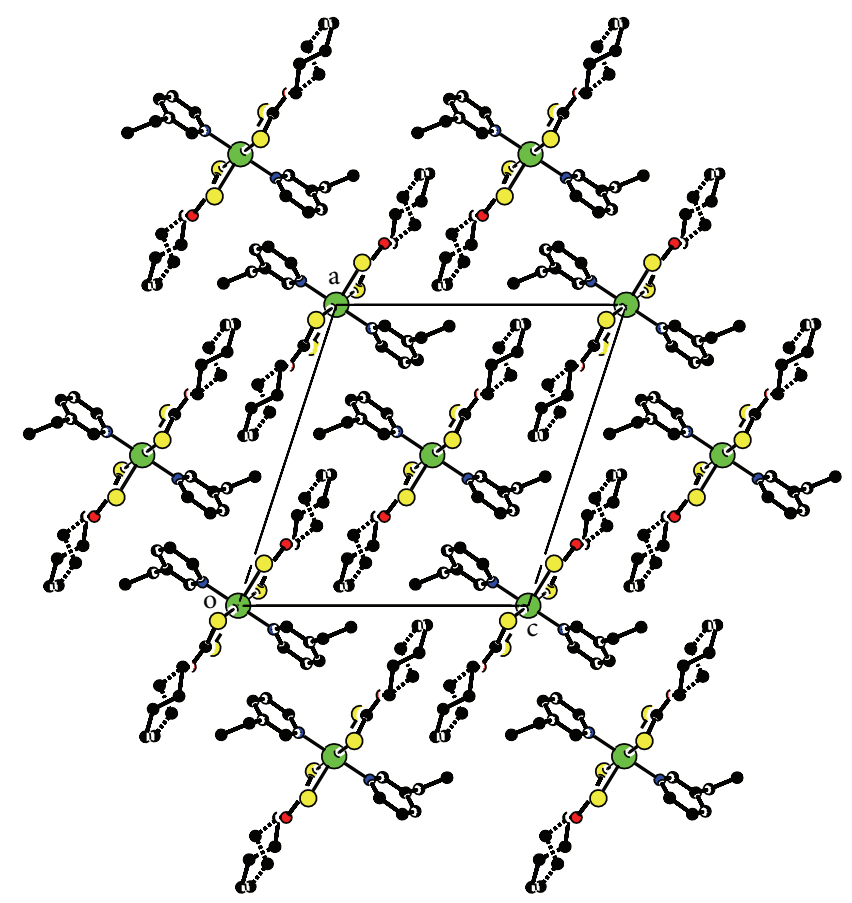

FIGURE 4: The packing arrangement of molecules viewed down the $b$-axis.

3.5. X-Ray Crystallographic Studies. The crystallography data for bis(O-butyldithiocarbonato)bis(3-ethyl pyridine) nickel(II) are presented in Table 3. Selected bond distances and bond angles for nonhydrogen atoms are listed in Table 4. A general view of the molecule indicating atom numbering scheme is shown in Figure 3. Ortep-3 software [15] was used for making the thermal ellipsoids. The geometry of the molecule was calculated using PLATON [16] and PARST [17] software.

The asymmetric unit comprises half molecule and nickel(II) cation lies on an inversion centre. The $\mathrm{Ni}(\mathrm{II})$ atom is coordinated by a distorted octahedral arrangement of four sulphur atoms from two chelating xanthate ligands and two nitrogen atoms from two cyanopyridines ligands. 
TABLE 3: Crystal and experimental data.

\begin{tabular}{|c|c|}
\hline Empirical formula & $\mathrm{C}_{24} \mathrm{H}_{36} \mathrm{~N}_{2} \mathrm{NiO}_{2} \mathrm{~S}_{4}$ \\
\hline Formula weight & 571.50 \\
\hline Temperature & 293(2) K \\
\hline Wavelength & $0.71073 \AA$ \\
\hline \multicolumn{2}{|l|}{ Unit cell dimensions } \\
\hline$a, \AA ̊$ & $14.0721(6)$ \\
\hline$b, \AA$ & $7.0078(2)$ \\
\hline$c, \AA$ & $15.3604(7)$ \\
\hline$\alpha,{ }^{\circ}$ & 90.00 \\
\hline$\beta,{ }^{\circ}$ & $108.065(5)$ \\
\hline$\gamma,{ }^{\circ}$ & 90.00 \\
\hline$Z$ & 2 \\
\hline Space group & $P 2_{1} / \mathrm{n}$ \\
\hline Crystal system & monoclinic \\
\hline Calculated density, $\mathrm{g} / \mathrm{cm}^{-3}$ & 1.318 \\
\hline Absorption coeff., $\mathrm{mm}^{-1}$ & 0.986 \\
\hline$F(000)$ & 604 \\
\hline Crystal size mm & $0.30 \times 0.20 \times 0.10$ \\
\hline Color & Green \\
\hline Theta range for entire data collection & $3.43-29.07$ deg. \\
\hline Limiting indices & $-17 \leq h \leq 17,-8 \leq k \leq 8,-18 \leq l \leq 18$ \\
\hline Refinement method & Full matrix least squares on $F^{2}$ \\
\hline Reflections collected & 14671 \\
\hline Used in refinement & 1984 \\
\hline Parameters & 167 \\
\hline Goodness-of-fit on $F^{2}$ & 1.045 \\
\hline$R$ indices & $R_{1}=0.0545, w R_{1}=0.1293$ \\
\hline Largest diff. peak and hole & 0.79 and $-0.42 \mathrm{e}^{-3}$ \\
\hline
\end{tabular}

TABLE 4: Bond lengths ( $⿱$ ) $)$, bond angles, and torsion angles $\left({ }^{\circ}\right)$.

\begin{tabular}{|c|c|c|c|}
\hline \multicolumn{4}{|c|}{ Bond distances $(\AA)$} \\
\hline Nil N6 & $2.112(3)$ & Nil S2 & $2.4436(11)$ \\
\hline Nil S1 & $2.4551(10)$ & S2 C1 & $1.677(5)$ \\
\hline $\mathrm{S} 1 \mathrm{Cl}$ & $1.684(4)$ & $\mathrm{C} 12 \mathrm{C} 13$ & $1.466(8)$ \\
\hline $\mathrm{C} 8 \mathrm{C} 12$ & $1.507(6)$ & $\mathrm{O} 2 \mathrm{C} 1$ & $1.340(5)$ \\
\hline $\mathrm{O} 2 \mathrm{C} 2 \mathrm{~B}$ & $1.426(9)$ & $\mathrm{O} 2 \mathrm{C} 2 \mathrm{~A}$ & $1.432(8)$ \\
\hline \multicolumn{4}{|c|}{ Bond angles $\left({ }^{\circ}\right)$} \\
\hline N6-Ni1-S2 & $90.31(9)$ & N6-Nil-S1 & $89.26(9)$ \\
\hline S2-Ni1-S1 & $106.63(4)$ & $\mathrm{C} 1-\mathrm{S} 2-\mathrm{Nil}$ & $83.03(14)$ \\
\hline C1-S1-Nil & $82.53(16)$ & $\mathrm{C} 13-\mathrm{C} 12-\mathrm{C} 8$ & $115.2(5)$ \\
\hline $\mathrm{O} 2-\mathrm{C} 1-\mathrm{S} 2$ & $117.5(3)$ & $\mathrm{O} 2-\mathrm{C} 1-\mathrm{S} 1$ & $121.5(3)$ \\
\hline \multicolumn{4}{|c|}{ Torsion angles $\left({ }^{\circ}\right)$} \\
\hline C9-C8-C12-C13 & $-66.2(8)$ & N6-Nil-S2-C1 & $-88.76(16)$ \\
\hline $\mathrm{C} 7-\mathrm{C} 8-\mathrm{C} 12-\mathrm{C} 13$ & $113.5(6)$ & S2-Ni1-N6-C7 & $-55.4(3)$ \\
\hline $\mathrm{C} 10-\mathrm{C} 9-\mathrm{C} 8-\mathrm{C} 12$ & $-179.2(5)$ & C9-C8-C12-C13 & $-66.2(8)$ \\
\hline
\end{tabular}


The Nil-N6 bond length is 2.112(3) $\AA$. The Ni-S bond lengths involving the xanthate ligands are 2.455(1) $\AA$ for Nil-S1 and 2.444(1) $\AA$ for Ni1-S2. The O2-C1 bond distance [1.340(5) $\AA]$ is shorter than $\mathrm{O} 2-\mathrm{C} 2 \mathrm{~A}[1.432(8) \AA]$ as a consequence of the hybridization of the carbon atom. The short value of bond distance for $\mathrm{O} 4-\mathrm{C} 3$ is consistent with a significant contribution of the resonance form of the xanthate anion that features a formal $\mathrm{C}=\mathrm{O}$ and a negative charge on each of $\mathrm{S}$ atom [18]. The $\mathrm{C}-\mathrm{S}$ bond lengths involving the xanthate ligands are $\mathrm{S} 1-\mathrm{C} 1=1.684(4)$ and $\mathrm{S} 2-\mathrm{C} 1=1.677(5) \AA$. These values show double bond character due to the delocalization over the two C-S bonds [19].

The bond angles in the pyridine ring vary from $117.8(4)$ to $124.1(4)^{\circ}$, the average value being $119.9(8)^{\circ}$, and these values of bond angles and bond distances are in good agreement with those reported for some analogous $\mathrm{Ni}$-dithiocarbonato complexes [20-23]. The plane formed by the atoms Nil, S1, $\mathrm{C} 1$, and S2 makes a dihedral angle of $88.20(9)^{\circ}$ with the plane of ethyl-pyridine ring, meaning thereby that both planes are held almost perpendicular to each other. The atom $\mathrm{C} 13$ of the ethyl group is deviated significantly from the plane of pyridine ring [deviation being $1.200(8) \AA$ ]. The butyl chain attached to the dithiocarbonato group contains disorder over two sets of sites with occupancy ratio of 0.572: 0.427 .

The packing of the molecule within the unit cell viewed down the $b$-axis is shown in Figure 4. Molecules in the unit cell are arranged in the form of layers and within the layers the molecules are parallel to each other. Nickel atom is located at each corner of the unit cell and also within the unit cell. The molecules are packed with Van der Waals contacts.

\section{Conflict of Interests}

The authors declare that there is no conflict of interests regarding the publication of this paper.

\section{Acknowledgment}

One of the authors (Rajni Kant) acknowledges the Department of Science \& Technology for single crystal X-ray diffractometer as a national facility sanctioned by the Ministry of Science and Technology, Government of India, under research Project no. SR/S2/CMP-47/2003.

\section{References}

[1] E. R. T. Tiekink and I. Haiduc, "Stereochemical aspects of metal xanthate complexes: molecular structures and supramolecular self-assembly," Progress in Inorganic Chemistry, vol. 54, pp. 127319, 2005.

[2] E. R. T. Tiekink and G. Winter, "Inorganic xanthates: a structural perspective," Reviews in Inorganic Chemistry, vol. 12, article $183,1992$.

[3] M. Wang, Qi. Zhang, W. Hao, and Z.-X. Sun, "Surface stoichiometry of zinc sulfide and its effect on the adsorption behaviors of xanthate," Chemistry Central Journal, vol. 5, pp. 7383, 2011.

[4] V. K. Jain, A. Wadawale, N. P. Kushwah, and M. K. Pal, "Organogallium and indium complexes with dithiolate and oxo ligands: synthesis, structures and applications," Journal of Chemical Sciences, vol. 123, no. 2, pp. 107-112, 2011.

[5] A. J. Odola and J. A. O. Woods, "New nickel (II) mixed ligand complexes of dithiocarbamates with Schiff base," Journal of Chemistry and Pharmaceutical Research, vol. 3, no. 6, pp. 865871, 2011.

[6] Oxford Diffraction, CrysAlis PRO, Oxford Diffraction Ltd, Abingdon, UK, 2007.

[7] G. M. Sheldrick, "A short history of SHELX," Acta Crystallographica, vol. A64, pp. 112-122, 2008.

[8] B. S. Furniss, A. J. Hannaford, P. W. G. Smith, and A. R. Tatchell, Vogel's Text Book of Practical Organic Chemistry, Pearson Education, London, UK, 5th edition, 1989.

[9] R. L. Martin and A. Whitley, "Magnetic studies with copper(II) salts. Part III. The constitution of copper(II) n-alkanoates in solution," Journal of the Chemical Society, pp. 1394-1402, 1958.

[10] W. J. Geary, "The use of conductivity measurements in organic solvents for the characterisation of coordination compounds," Coordination Chemistry Reviews, vol. 7, pp. 81-122, 1971.

[11] F. Basolo and W. R. Matousch, "Changes in configuration of some Nickel(II) complexes," Journal of the American Chemical Society, vol. 75, pp. 5663-5666, 1953.

[12] D. Coucouvains and J. P. Fackler, "Square-planar sulfur complexes. VI. Reactions of bases with xanthates, dithiocarbamates, and dithiolates of nickel(II)," Inorganic Chemistry, vol. 6, pp. 2047-2053, 1967.

[13] H. Zagal and J. A. Costamagna, "Complexes from tri-nbutylphosphine and xanthates of nickel(II)," Inorganic and Nuclear Chemistry Letters, vol. 13, pp. 411-416, 1977.

[14] A. B. P. Lever, Inorganic Electronic Spectroscopy, Elsevier, Amsterdam, The Netherlands, 1984.

[15] L. J. Farrugia, "ORTEP-3 for Windows-a version of ORTEPIII with a Graphical User Interface (GUI)," Journal of Applied Crystallography, vol. 30, p. 565, 1997.

[16] A. L. Spek, "Structure validation in chemical crystallography," Acta Crystallographica D, vol. 65, pp. 148-155, 2009.

[17] M. Nardelli, "PARST95-an update to PARST: a system of Fortran routines for calculating molecular structure parameters from the results of crystal structure analyses," Journal of Applied Crystallography, vol. 28, p. 659, 1995.

[18] N. Alam, M. A. Ehsan, M. Zeller, M. Mazhar, and Z. Arifin, "Bis(O-n-butyl dithiocarbonato- $\left.\kappa^{2} \quad S, S^{\prime}\right)$ bis-(pyridineN)manganese(II)," Acta Crystallographica E, vol. 67, no. 8, p. m1064, 2011.

[19] X. H. Jiang, W. G. Zhang, Y. Zhong, and S. L. Wang, "Synthesis and structure of the cadmium (II) complex: $\left(\left[\mathrm{Cd}\left(\mathrm{C}_{5} \mathrm{H}_{5} \mathrm{~N}\right)_{2}\right.\right.$ $\left.\left(\mathrm{S}_{2} \mathrm{CO}-\mathrm{n}-\mathrm{C}_{4} \mathrm{H}_{9}\right)_{2}\right]$," Molecules, vol. 7, no. 7, pp. 549-553, 2002.

[20] S. Kapoor, R. Sachar, K. Singh, V. K. Gupta, and Rajnikant, "Synthesis, characterization and X-Ray structure of Bis(O-propyldithiocarbonato- $\kappa^{2} \quad$ S, $\left.S^{\prime}\right)$ bis (4-cyanopyridine- $\left.\kappa N\right)$ nickel(II)," Journal of Chemical Crystallography, vol. 42, pp. 458-463, 2012.

[21] S. Kapoor, R. Kour, R. Sachar, R. Kant, V. K. Gupta, and K. Kapoor, "Bis(O-ethyl dithiocarbonato- $\kappa^{2}$ S, $\left.\mathrm{S}^{\prime}\right)$ bis-(pyridine-3carbonitrile- $\kappa \mathrm{N}^{1}$ )nickel(II)," Acta Crystallographica E, vol. 68, no. 1, p. m58, 2012.

[22] K. Singh, I. Kour, G. Kour, R. Sachar, V. K. Gupta, and Rajnikant, "Synthesis and crystal structure of Bis(O-ethyldithiocarbonato)bis(4-ethylpyridine)nickel(II)," X-Ray Structure Analysis Online, vol. 28, pp. 69-70, 2012.

[23] Neerupama, R. Sachar, N. Sambyal et al., "Synthesis, characterization and X-ray structure of the adducts of bis $(\mathrm{O}$ butyldithiocarbonato)nickel(II) with substituted pyridines," Acta chimica Slovenica, vol. 60, pp. 397-402, 2013. 

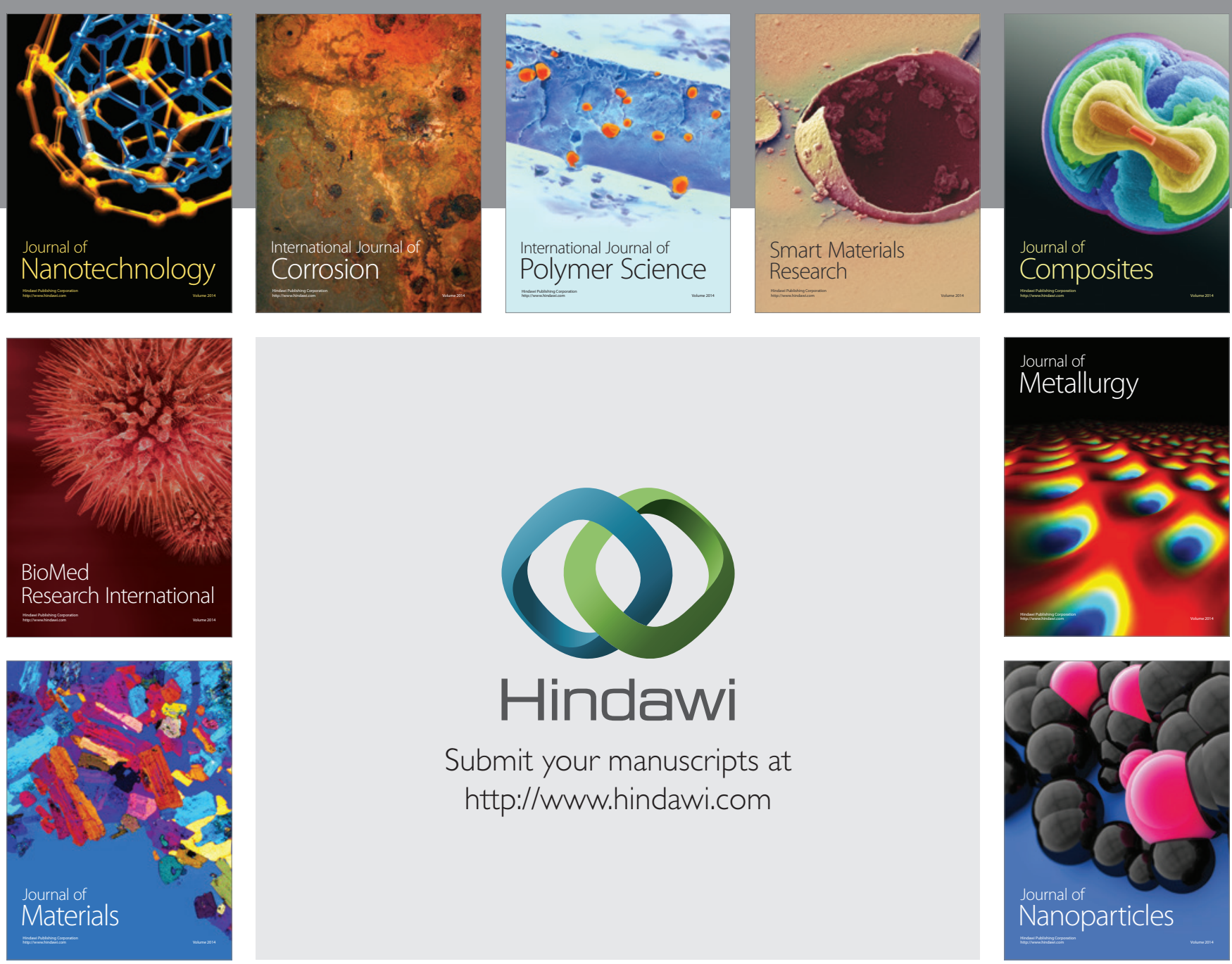

Submit your manuscripts at http://www.hindawi.com
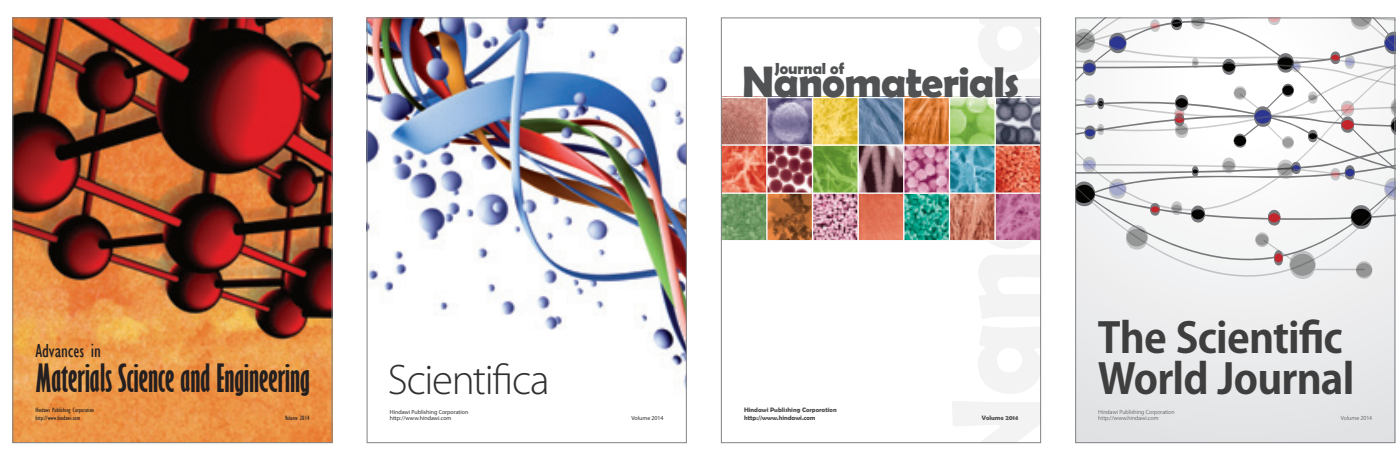

\section{The Scientific World Journal}
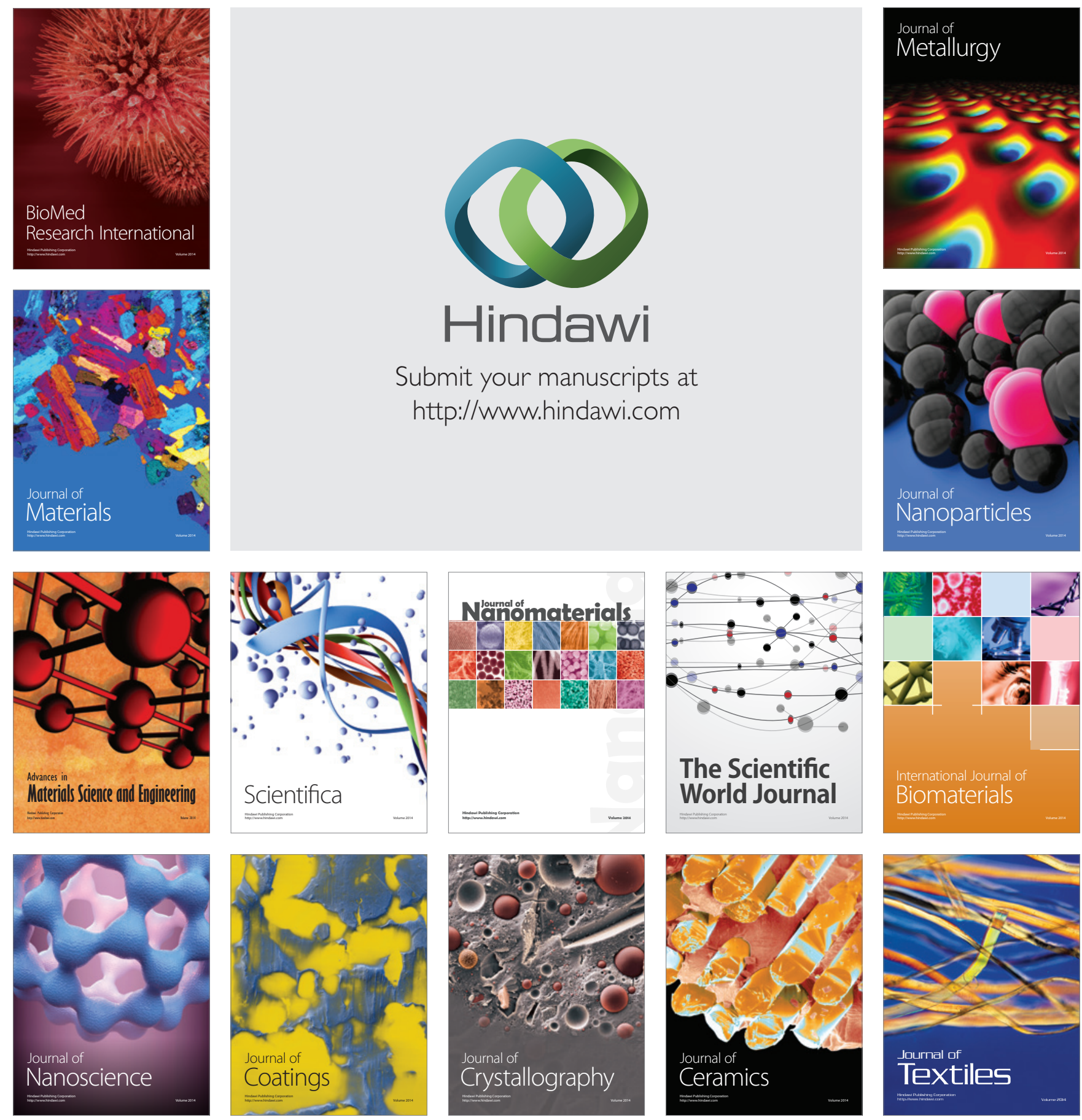